\title{
Comparative assessment of the potential of the regions of the zone of influence of the Great Silk and Tea Road
}

\author{
NATALYA LUBSANOVA, ANNA MIKHEEVA \\ Laboratory of Environment Economy \\ Baikal Institute of Nature Management Siberian branch of the Russian Academy of sciences \\ 8 Sakhyanovoy str., Ulan-Ude, 670047 \\ RUSSIA
}

\begin{abstract}
This article proposes a new approach to assessing the economic potential of the regions affected by transport corridors as part of the implementation of the Great Silk and Tea Road initiatives. The proposed methodology is based on the calculation of an integral indicator, which includes five indexes of subpotentials: industrial, labor, food, innovation and financial. To calculate these indices, we used indicators of economic development, such as the volume of gross regional product per capita, the volume of gross value added under the heading "Manufacturing production", "Agriculture", "Financial activity" per capita, population density, economically active population, average monthly wage, number of research and development staff. In calculating the indices, their weights were taken into account, defined on the basis of the probability approach using the matrix of paired preferences. The methodology was tested in 28 regions of China, Mongolia, Russia, and Kazakhstan in the context of five alternative transport corridors: three routes of the China-Mongolia-Russia economic corridor, the corridor "Western Europe - Western China", corridor "Dostyk-Alashankou Mikhailovka-Uba". Prospects for the implementation of transport corridor programs are largely determined by the economic potential of the regions of the zone of influence, the efficiency of its use and the existing economic conditions. Assessment of the economic potential of the regions as a cumulative ability to carry out production and economic activities, meet the needs of the population will reveal promising areas of development, identify the problem points of implementation of programs. The effective development of transport corridors will contribute to increase international and interregional trade, including E-commerce, and investment; plays a pivotal role in integrating economies across regions. It's results in reducing the costs of transportation, both within and across regions, improving international market access, increasing income, and reducing poverty.
\end{abstract}

Key-Words: - Transport corridors, the Great Silk and Tea Road initiatives, the economic potential, the ChinaMongolia-Russia economic corridor, the corridor "Western Europe - Western China", China, Mongolia, Russia, Kazakhstan

Received: April 23, 2019. Revised: May 22, 2020. Accepted: June 8, 2020. Published: June 10, 2020

\section{Introduction}

One of the main trends in the modern development of the world economy is the strengthening of integration processes between countries, as evidenced by the increase in the number of regional economic associations. According to the World Trade Organization, currently there are about 300 existing regional trade agreements in the world, including agreements on economic integration, on the formation of customs unions and agreements with a partial scope of action that apply to a certain list of products. The most important factor in global geoeconomic transformations is the One Belt, One Road Initiative launched in 2013, which aims to "establish closer ties between the countries of Asia, Europe and Africa and raise mutually beneficial cooperation of these countries to a new historical height" [1]. As part of the initiative, the PRC proposes to develop international cooperation in five main areas: "political coordination, interconnection of infrastructures, uninterrupted trade, free circulation of capital and strengthening spiritual closeness between peoples" [1].

In this context, the initiative to create the ChinaMongolia-Russia international economic corridor, approved by the leaders of the three countries, is very important, which fits organically into triangular cooperation plans, contributing to the integration of regional development strategies: the Chinese Silk Road Economic Belt, the Mongolian Steppe Way and the Russian initiative of Eurasian Economic Union. The creation of this trilateral economic corridor can serve as a strong impetus for the development of the territories adjacent to it. 


\section{Problem Formulation}

Prospects for the development of integration processes are largely determined by the economic potential of the regions, the effectiveness of its use and existing economic conditions. The implementation of the China-Mongolia-Russia Economic Corridor program involves the creation of an integrated infrastructure network that will provide "connection between economic nodes or hubs, usually centered on urban landscapes, in which large amount of economic resources and actors are concentrated" [2, p.9]. Under these conditions, a necessary stage in assessing the prospects for the development of the economic corridor is the development of methodological approaches to assessing the economic potential of the territories in question $[3,4]$.

\subsection{Overview of approaches to the definition of "economic potential"}

In economic literature, the term "economic potential" is mainly used in macroeconomics. M.Roberts defines the term as "the extent to which a district possesses factors which are important determinants of the ability to experience a high level of productivity" [5]. World Bank experts under economic potential understand the level of productivity that a region can achieve given its structural characteristics [6]. Structural characteristics are factors that influence productivity and economic development. They are static and cannot be changed in the short term. Such structural factors include the level of urbanization, access to markets, the quality of human capital (duration or proportion of people with higher education), the geographical characteristics of the regions and the sectoral structure of the economy. Based on this approach, the World Bank has developed a methodology for the economic potential index of the regions, which allows to determine the structural characteristics that best explain the levels of productivity observed by region [6].

In Soviet economic science, this category is defined as "the maximum capacity of the economic system, which determines the maximum possible volume of production of material goods and services that can be achieved under ideal production conditions and the optimal use of resources" [7, p.13]. Currently, in the scientific literature there are two main approaches to the definition of this concept:

1. as a set of available capabilities, in particular, means of production, stocks, productive forces, etc. that can be used to solve a problem, achieve a specific goal $[8,9,10]$;

2. as a measure of the use of resources (labor, natural, industrial, financial, etc.) based on the definition of promising and achieved potential [1115].

In our opinion, the most accurate reflection of the essence of the concept of "economic potential" is the first approach, according to which by economic potential we mean the combined ability to carry out production and economic activities, to satisfy the needs of the population.

\subsection{Overview of approaches to assessing the economic potential of regions}

It is worth noting that the diversity of approaches to the definition of the category of "economic potential" determines the presence of many methodological approaches to its assessment. The most universal and recognized is the approach based on the construction of an integral indicator, which includes estimates for each of the basic evaluation indicators. On this basis, many techniques have been developed and applied both in domestic and in foreign practice. These include the methodology developed by the World Bank Group, which was used to study regional development in India and the countries of the European Union based on the index of economic potential, which includes indicators: Market access, Economic density, level urbanization (Level of urbanization), human capital (human capital), transport accessibility (local transport connectivity); the methodology of the Analytical Center under the Government of the Russian Federation with the addition of performance indicators, sectoral composition of the economy and the impact of centralized planning; the methodology of the Ministry of Economic Development for a comprehensive assessment of the level of economic development of the regions $[5,6,16]$. It is also worth highlighting some studies of economic potential in single sectors. These include the work of B.A Kheyfets, V.Yu. Chernova in the field of Agri-Food Sector, in which they use indicators of foreign direct investment, mutual trade and innovative activity on the example of the EAEU countries [17]. In the field of railway transport, one can single out a study by a team of 
authors led by Ospankulov E.E. across Kazakhstan [18].

The reviewed approaches used to assess economic potential are mainly carried out at the country level, or at the level of territories (regions), the assessment is carried out for one country. The author's approach to the comparative assessment of the economic potential of the territories proposed in the article allows for cross-country analysis in the context of territories. Which, when analyzing comparative options for transport corridors, allows us to assess the competitive advantages of options and form their effective development strategy.

\section{Problem Solution}

\subsection{Methodology}

To assess the potential of the regions of the regions of the zone of influence of the Great Silk and Tea Road, a methodology is proposed based on an integral indicator that includes five indexes of subpotentials: industrial, labor, food, innovation and financial:

$$
I_{\text {ep }}^{i}=I_{\text {ind }}^{i}+I_{\text {labor }}^{i}+I_{\text {food }}^{i}+I_{\text {innov }}^{i}+I_{\text {fin }}^{i},
$$

where $I_{e p}^{i}$ - index of economic potential of the ith region,

$I_{\text {ind }}^{i}$ - index of industrial potential of the i-th region,

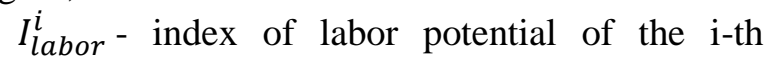
region,

$I_{\text {food }}^{i}$ - index of food potential of the i-th region,

$I_{\text {innov }}^{i}$ - index of innovation potential of the i-th region,

$I_{\text {fin }}^{i}$ - index of financial potential of the i-th region,

The index of industrial potential was determined by the following formula:

$$
\begin{aligned}
& I_{i n d}^{i}=\sum_{j=1}^{n} \alpha_{j} \bar{x}_{j}^{i}, \\
& i=1, \ldots, m ; j=1, \ldots, n,
\end{aligned}
$$

where $\alpha_{j}$ - the weight of the $\mathrm{j}$-th indicator of industrial potential,

$\bar{x}_{j}^{i}$ - normalized value of the $\mathrm{j}$-th indicator of the i-th region,

$n$ - the number of indicators of industrial potential,

$m$ - the number of regions.
Because indicators are expressed in different units, addition among indicators with different units was performed only after the different measurement units are normalized into a dimensionless scale. Normalization of indicators was carried out according to the difference between the best and worst values. Each indicator was normalized by using Eqs. 3 (if indicator positive), Eqs. 4 (if indicator negative).

$$
\begin{aligned}
\bar{x}_{j}^{i} & =\frac{x_{j}^{i}-x_{j}^{\min }}{x_{j}^{\max }-x_{j}^{\min },} \\
\bar{x}_{j}^{i} & =\frac{x_{j}^{\min }-x_{j}^{i}}{x_{j}^{\min }-x_{j}^{\max }},
\end{aligned}
$$

where $x_{j}^{i}$ - value of the $\mathrm{j}$-th indicator of the $\mathrm{i}$-th region,

$$
\begin{aligned}
& x_{j}^{\text {min }}-\text { minimal value of the } \mathrm{j} \text {-th indicator, } \\
& x_{j}^{\text {max }}-\text { value of the } \mathrm{j} \text {-th indicator. }
\end{aligned}
$$

The used normalization process estimates the value of potential's indicator of each region relative to the best region with better value performance. The normalization equations need to be applied to the modified full set, which, in turn, may change the which, in turn, may change the final outcome. The normalized values are dimensionless and range from 0 to 1 , therefore, the greater the absolute value of the normalized indicator, the better it is.

To determine the weights of indicators $\alpha_{j}$ in Eqs.2, a probabilistic approach was used based on a matrix of pairwise preferences [19]. Based on an array of normalized indicator values, a matrix was constructed, each element of which represents an assessment of the preference of one indicator over another. The criterion for the preference of the indicator was a smaller absolute deviation of its value from the average compared to another indicator. As noted by Frenkel A.A., Sergienko Y.V., Volkova N.N., Smirnov S.V., Roshchina L.S., the advantage of this method of finding weights is mathematical validity and objectivity. [20].

Labor, food, innovation and financial potentials were calculated using similar formulas.

\subsection{Results and Discussion}

Based on the developed methodology, the economic potential of the territories of Russia, China, Mongolia and Kazakhstan in the zone of influence of the Great Silk and Tea Road were assessed according to 2017. The territory was grouped according to alternative transportation corridors: three routes of the China-Mongolia- 
Russia economic corridor, the corridor "Western Europe - Western China", corridor "DostykAlashankou - Mikhailovka-Uba" (table 1). As can be seen from table 1, a total of 28 territories of China, Mongolia, Kazakhstan, and Russia were examined. There are 5 territories in the zone of influence of the Eastern route of the China-
Mongolia-Russia economic corridor, 5 of the Central route, 10 of the Western route, 8 of the Western Europe-Western China corridor, and 4 of the Dostyk-Alashankou-Mikhailovka-Uba corridor. Territories Inner Mongolia and Xinjiang of China, and Almaty region were included in the influence zone of several corridor route options.

Table 1. Grouping of territories of Russia, China, Mongolia and Kazakhstan in the zone of influence of the Great Silk and Tea Road

\begin{tabular}{|c|c|c|}
\hline Option & Territory & Country \\
\hline \multirow{3}{*}{$\begin{array}{l}\text { Eastern route of the China- } \\
\text { Mongolia-Russia } \\
\text { corridor }\end{array}$} & Inner Mongolia, Heilongjiang & China \\
\hline & Dornod, Sukhbaatar & Mongolia \\
\hline & Zabaykalsky krai & Russia \\
\hline \multirow{3}{*}{$\begin{array}{l}\text { Central route of the China- } \\
\text { Mongolia-Russia } \\
\text { corridor }\end{array}$} & Xinjiang & China \\
\hline & Uvs, Zavkhan, Govi-Altai & Mongolia \\
\hline & Republic Tuva & Russia \\
\hline \multirow{3}{*}{$\begin{array}{l}\text { Western route of the China- } \\
\text { Mongolia-Russia } \\
\text { corridor }\end{array}$} & Inner Mongolia, Hebei & China \\
\hline & $\begin{array}{l}\text { Selenge, Darkhan-Uul, Ulaanbaatar, Tuv, } \\
\text { Dundgovi, Dornogovi, Govisumber }\end{array}$ & Mongolia \\
\hline & Republic Buryatia & Russia \\
\hline \multirow{3}{*}{$\begin{array}{l}\text { Corridor "Western Europe } \\
\text { Western China" }\end{array}$} & Orenburg region & Russia \\
\hline & $\begin{array}{l}\text { Aktobe, Kyzylorda, Turkistan (formerly South } \\
\text { Kazakhstan), Jambyl, Almaty regions, Almaty } \\
\text { city }\end{array}$ & Kazakhstan \\
\hline & Xinjiang & China \\
\hline \multirow{3}{*}{$\begin{array}{l}\text { Corridor "Dostyk-Alashankou } \\
\text { Mikhailovka-Uba" }\end{array}$} & Altai krai & Russia \\
\hline & East Kazakhstan, Almaty regions & Kazakhstan \\
\hline & Xinjiang & China \\
\hline
\end{tabular}

Based on the analysis of methodological approaches to assessing the economic potential of the regions and the availability and comparability of data, eight indicators were determined that characterize the production, labor, food, innovation, and financial potentials of the regions. A matrix of pairwise comparisons of the values of these indicators for 2017 for the selected territories $(Q)$ was compiled. Each element of this matrix $q_{j k}$ can be interpreted as the probability of preference of the indicator $j$ to the indicator $k$. The criterion for the preference of the indicator is a smaller absolute deviation of its value from the average compared to another indicator. The values of the elements of the matrix were determined by the following formula:

$$
q_{j k}=\frac{m_{j}}{m_{k}}
$$

where $m_{j}$ - the number of cases when the indicator $j$ is "better" than the indicator $k$ (that is, it has a smaller absolute deviation of the private indicator from the average);

$m_{k}$ - the number of cases where, respectively, the indicator $k$ is preferable to the indicator $j$.

In the pairwise preference matrix $Q$, each element is positive, $q_{j k}=1 / q_{j k}$, and the diagonal elements are 1 . The weight vector $\alpha_{j}$ can be defined as an eigenvector of the matrix. Normalizing the eigenvector, we obtain an estimate of the weight vector $A\left(a_{1}, \ldots, a_{j}, \ldots, a_{m}\right)$.

As a result of the calculations the following values of the weights of indicators of the economic potential were obtained (table 2).

Table 2. The values of the weights of indicators of economic potential

\begin{tabular}{|c|l|c|}
\hline Subpotentials & Indicator & Weight of indicator \\
\hline Industrial potential & Per capita gross regional product, thousand. \$ (PPP) & 1.147 \\
\cline { 2 - 3 }
\end{tabular}




\begin{tabular}{|l|l|c|}
\hline \multicolumn{1}{|c|}{ Subpotentials } & \multicolumn{1}{|c|}{ Indicator } & Weight of indicator \\
\hline \multirow{2}{*}{ Labor potential } & $\begin{array}{l}\text { Gross value added per capita under «Manufacturing } \\
\text { production» section, thousand. \$ (PPP) }\end{array}$ & 1.142 \\
\cline { 2 - 3 } & $\begin{array}{l}\text { Eopulation density, persons/km2 } \\
\text { persons }\end{array}$ & 0.952 \\
\cline { 2 - 3 } & Average monthly wage, \$(PPP) per person. & 1.038 \\
\hline Food potential & $\begin{array}{l}\text { Gross value added per capita under «Agriculture» } \\
\text { section, thousand. \$ (PPP) }\end{array}$ & 0.888 \\
\hline Innovation potential & $\begin{array}{l}\text { Number of research and development staff per 1,000 } \\
\text { population, persons }\end{array}$ & 0.952 \\
\hline Financial potential & $\begin{array}{l}\text { Gross value added per capita under «Financial activity» } \\
\text { section, thousand. \$ (PPP) }\end{array}$ & 1.086 \\
\hline
\end{tabular}

Based on the obtained values of weights and normalized values of indicators for 2017, the indices of economic potential were calculated for the analyzed 28 territories. The results are shown in Figure 1. As can be seen from the diagram an assessment of the economic potential in the context of this group indicates the greatest economic potential of the regions included in the zone of influence of the central variant of the ChinaMongolia-Russia corridor. The maximum level of economic potential was noted in the city of Almaty.
For all components of the economic potential, the excess of the indices of this option over the others is determined. Thus, the index of industrial potential of the regions included in the zone of influence of the central variant of the ChinaMongolia-Russia corridor is 5.03, while next group by the value of this index (the "Western EuropeWestern China" corridor) is 4.53 . The maximum values were observed in the cities Almaty, Ulaanbaatar, aimag Dornod. 


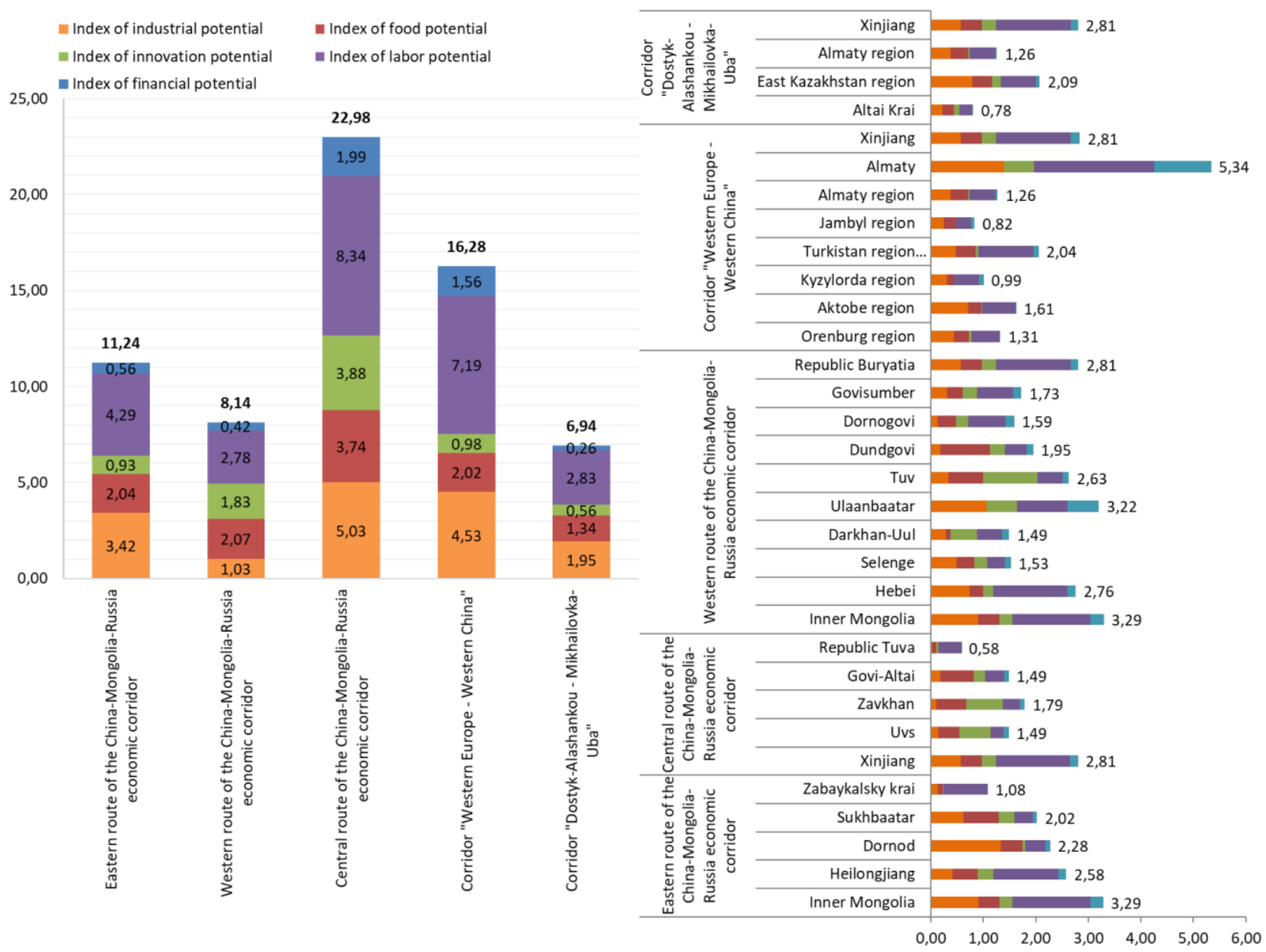

Fig. 1. Assessment of the potential of the territories of Russia, China, Mongolia and Kazakhstan in the zone of influence of the Great Silk and Tea Road

The highest index of food potential was also determined for the central option of the ChinaMongolia-Russia corridor (3.74), slightly lower than the value for the option of the "Western Europe-Western China" corridor (2.02), eastern (2.04) and western (2.07) options for the ChinaMongolia-Russia corridor. Aimags Dundgovi, Sukhbaatar, Tuv, Govi-Altai are the leaders in this indicator.

The largest gap between the corridor options was found in terms of innovation potential: the central option of the China-Mongolia-Russia corridor was 3.88 , the western option of the ChinaMongolia-Russia corridor was next with 1.83 . According to our estimations, the greatest innovative potential have Almaty, Ulaanbaatar, Darkhan-Uul, aimags Zavkhan and Tuv.

A large contribution to the formation of economic potential is made by the labor potential: the central option has index 8.34, "Western EuropeWestern China" - 7.19.

The financial potential index as well as the innovative one showed a significant differentiation of corridor options, a high level of the central option of the China-Mongolia-Russia corridor and the "Western Europe-Western China" corridor (1.99 and 1.56, respectively) and the much lower values of the other three options $(0.56,0.42$ and 0.26 ), which may indicate the underdevelopment of innovative and financial infrastructure in the regions that are in the influence zone of the western and eastern options of the China-Mongolia-Russia corridor and the corridor "Dostyk-Alashankou Mikhailovka-Uba".

\section{Conclusion}

As a result of assessing the economic potential of the territories of Russia, China, Mongolia and Kazakhstan in the zone of influence of the Great Silk and Tea Road in the context of five alternative transport corridors, it can be concluded that the development of the central spatial orientation option of the China-Mongolia-Russia economic corridor, as having the greatest economic potential 
is a priority. For all components of the economic potential, the excess of the indicators of this option over the others is determined. It is determined that the territories with the corridor "DostykAlashankou - Mikhailovka-Uba" possess the least economic potential. It was revealed that the most significant lag behind the leader option was observed in the indices of innovative and financial potential, which indicates the underdevelopment of innovative and financial infrastructure. The implementation of appropriate state policies in these areas in the territories would help to overcome this gap.

Thus, the proposed methodology allows us to assess the existing economic condition of the regions, compare alternative options for the development of transport corridors, identify priority routes, as well as problem points of regional development.

In continuation of the study, it is planned to assess the economic potential in dynamics since 2010 (the year of launch of the "One Belt, One Way" initiative) in order to identify risks and determine strategic directions for the development of economic processes of the regions of the zone of influence of the Great Silk and Tea Road.

\section{Acknowledgments}

The paper was prepared as part of a state assignment of Baikal Institute of Nature Management Siberian branch of the Russian Academy of sciences.

\section{References:}

[1] Vision and Actions on Jointly Building Silk Road Economic Belt and 21st-Century Maritime Silk Road. Available at: http://en.ndrc. gov.cn/newsrelease/201503/t20150330_66936 7.html.

[2] Brunner Hans-Peter, What is Economic Corridor Development and What Can It Achieve in Asia's Subregions? ADB Working Paper Series on Regional Economic Integration, No.117, 2013. https://www.adb.org/sites/default/files/publicat ion/100110/reiwp-117-economic-corridordevelopment.pdf.

[3] Mikheeva A.S., Lubsanova N.B., Prospects for the development of cooperation between Russia, China and Mongolia in the context of Eurasian interaction, Moscow Economic Journal, No.3, 2018. pp. 7-12.
[4] Mikheeva A.S., Petrova A.A., Modern integration processes in the subregions of Asian Russia and adjacent territories, Business. Education. Law, No.3 (48), 2019, pp. 81-86.

[5] Roberts M., Identifying the Economic Potential of Indian Districts, World Bank Policy Paper 7623, Social, Urban, Rural and Resilience Global Practice Group, 2016)=.

[6] Farole T., Roberts M., Park J., and Hooton C., Assessing the Economic Potential of Europe's Regions. Washington, DC: World Bank, 2018.

[7] Great Soviet Encyclopedia, Vol.20, Soviet Encyclopedia, 1975.

[8] Lyubimova M.V., Nesterov V.P., Dmitrieva V.S. Problems of assessing the socioeconomic potential of the region, Regional Economics: theory and practice, No.4, 2007. pp.13-14.

[9] Pechatkin V.V., Investment and innovation development of Russian regions: key problems and directions for their solution, Economic revival of Russia, No.3, 2013. pp.75-78.

[10] Rastvortseva S.N., The essence of the socioeconomic efficiency of the development of the region, Regionology, No.4, 2008, pp. 130-135.

[11] Vavilova A.Yu., Letchikov A.V., Sokolova M.A., Econometric model of rating assessment of the regions of the Volga Federal District based on socio-economic potential, Bulletin of the Udmurt University, No.2, 2006, pp.31-43.

[12] Belomestnov V.G., Management of the potential of the socio-economic systems of the region, ROST, 2005.

[13] Muftakhutdinova Kh.R., Gorinov M.N., The economic potential of the region: socioeconomic essence and model of assessment, Bulletin of the Izhevsk State Technical University, No.4. 2007, pp.30-36.

[14] Klotsvog F., Kushnikova I., Resource potential of subjects of the federation and its use, Economist, No.12. 1998, pp. 33-39.

[15] Tishchenko A.N., Davyskiba E.V., Evaluation of the effectiveness of the use of the economic potential of the region, Communal services of cities: scientific and technical collection, No.56. 2004. pp. 3-13.

[16] Sivaev D., Cineas G., Milentey A., Gosnell Yu., Shadrunova T., Dalgleish E., Pryadilnikov M., Steshenko A., Silchuk A., Re-mapping opportunity : making best use of the economic potential of Russia's regions, World Bank Group, 2018. http://documents.worldbank.org/curated/en/48 3301521139382232/Re-mapping-opportunity- 
making-best-use-of-the-economic-potentialof-Russias-regions

[17] Kheyfets B.A., Chernova V.Yu. Potential of Cooperation of the EAEU Countries in the Perspective of Digitalization of the Agri-Food Sector, WSEAS Transactions on Business and Economics, Vol.17, 2020, pp. 85-92

[18] Ospankulov E.E., Seitkazieva A.M., Bolatkyzy S., Sharipov A., Gussenov B.Sh., Assanova Zh., Bekmetova A., Kazieva L., Mussina T., Berkinbayeva Ye. The Development of Rail Transport and Its Impact on the National Economy \& Foreign Economic Activity of the Republic of Kazakhstan, WSEAS Transactions on Business and Economics, Vol.16, 2019, pp. 433-443.

[19] Gupta S., Wilton P.C., Combination of forecasts: an extension, Management Science, Vol.33, No.3, 1987, pp. 356-372

[20] Frenkel A.A., Sergienko Ya.V., Volkova N.N., Smirnov S.V., Roshchina L.S., Some approaches to the construction of integral indices of the economic development of Russia, Economics and Entrepreneurship, No.11 (part 1), 2015, pp.86-91.

[21] Otgonsuren B., Mongolia-China-Russia Economic Corridor Infrastructure Cooperation. ERINA Report, No.127, 2015, pp.3-6. http://www.erina.or.jp/wpcontent/uploads/2015/02/se12710_tssc.pdf.

[22] Soni S.K., China-Mongolia-Russia Economic Corridor: Opportunities and Challenges. In: Deepak B. (eds) China's Global Rebalancing and the New Silk Road, Springer, 2018. https://link.springer.com/chapter/10.1007/978981-10-5972-8_9.

[23] Dorzh T., Davaasuren A., The role of the central transport corridor of Mongolia in the development of the economic corridor of the three countries, Eurasian cooperation: humanitarian aspects, No., 2017, pp. 42-51.

\section{Creative Commons Attribution}

\section{License 4.0 (Attribution 4.0 International , CC BY 4.0)}

This article is published under the terms of the Creative Commons Attribution License 4.0 https://creativecommons.org/licenses/by/4.0/deed.e n_US 